\title{
Lifelong n-3 Polyunsaturated Fatty Acid Exposure Modulates Size of Mammary Epithelial Cell Populations and Expression of Caveolae Resident Proteins in Fat-1 Mice
}

\author{
Lyn M. Hillyer ${ }^{1}$, Jing X. Kang ${ }^{2}$ and David W.L. Ma ${ }^{1, * \mathbb{D}}$ \\ 1 Department of Human Health and Nutritional Sciences, University of Guelph, Guelph, ON N1G 2W1, \\ Canada; lhillyer@uoguelph.ca \\ 2 Massachusetts General Hospital and Harvard Medical School, Boston, MA 02114, USA; \\ kang.jing@mgh.harvard.edu \\ * Correspondence: davidma@uoguelph.ca; Tel.: +1-519-824-4120 (ext. 52272)
}

Received: 14 August 2019; Accepted: 5 October 2019; Published: 15 October 2019

\begin{abstract}
Omega-3 polyunsaturated fatty acids (n-3 PUFA) have been associated with reduced breast cancer risk; however, the exact mechanism remains elusive. Female wildtype (WT) and fat-1 mice were fed a 10\% safflower diet until 6 weeks of age. Mammary gland epithelial cells (EC) were isolated and EC populations were determined by CD24 surface expression. Fat- 1 mice expressed $65 \%, 20 \%$, and $15 \%$ while WT mice expressed $65 \%, 26 \%$ and $9 \%$ for non-, myo- and luminal ECs, respectively. The luminal EC population was significantly greater in fat-1 mice $(p \leq 0.05)$, while the total number of mammary ECs were similar between groups $(p=0.79)$. Caveolae was isolated from ECs and Her-2/neu, ER- $\alpha$ and cav-1 protein expression was determined by Western blotting. Fat- 1 mice had a two-fold greater ER- $\alpha(p \leq 0.05)$ and a 1.5-fold greater cav-1 $(p \leq 0.05)$ expression than WT with a similar amount of Her-2/neu protein $(p=0.990)$ between groups. Overall, this study provides novel mechanistic evidence by which n-3 PUFA modifies early mammary gland development that may potentially reduce breast cancer risk later in life.
\end{abstract}

Keywords: n-3 PUFA; fat-1 mice; caveolae; ER- $\alpha$; Her-2/neu; breast cancer

\section{Introduction}

While breast cancer morbidity has declined over the past decade, it remains the most prevalent form of cancer and leading cause of cancer-related mortalities in females worldwide [1-5]. However, incidence rates in Western civilizations are twice as high as those in Asian countries [6,7]. Recent evidence has shown that lifelong consumption of n-3 polyunsaturated fatty acids (PUFA) inhibits mammary tumour growth, as well as modulates mammary gland development [8-10]. During puberty female rodents experience expansive terminal end bud (TEB) development which has been identified as the site of mammary tumour initiation [11]. Additionally, the consumption of n-3 PUFA has been shown to reduce the number of TEBs by modulating mammary epithelial cell differentiation and increasing the number of lobular alveolar structures [12].

The TEB within rodent mammary glands are formed from two epithelial cell populations, luminal epithelial cells $\left(\mathrm{CD} 24^{+/ \text {high }}\right)$ and myo-epithelial cells $\left(\mathrm{CD} 24^{+/ \text {low }}\right)$ [13]. Evidence indicates that luminal epithelial cells as the main site for breast cancer initiation while myo-epithelial cells provide ductal integrity and act to suppress tumour growth and invasion [14-16]. Additionally, few breast carcinomas contain fully differentiated myo-epithelial cells and the ones which do, lack the ability to produce sufficient amounts of functional laminin-1, a key regulator of luminal epithelial cell polarity [15-17]. 
The lack of mature myo-epithelial cells in mammary gland tumours may indicate a loss of ductal structure, as well as a reduction in cell-mediated signaling with the luminal epithelia.

Caveolae are plasma membrane domains found in abundance on the surface of epithelial cells and act as key regulatory sites for signal transduction. Due to their fluidic nature, caveolae are thought to play a role in cellular diseases, such as breast cancer [18,19]. Three major proteins associated with caveolae and breast cancer are caveolin-1 (cav-1), human epidermal growth factor receptor 2 (Her-2/neu) and estrogen receptor- $\alpha(\mathrm{ER}-\alpha)$. Cav-1 is the principle quantitative marker for caveolae and is believed to have tumour-suppressing capabilities by improving caveolae formation and consequently, cell signaling [19-21]. The over expression of ER- $\alpha$ and Her-2/neu are biomarkers for aggressive types of breast cancer as activation of either receptor stimulates proliferatory pathways by increasing DNA replication, which increases the possibility of cancer-causing mutations [22,23].

In this preliminary study, the transgenic fat- 1 mouse was used to determine the effects of n-3 PUFA on mammary gland epithelial cell populations and signalling molecules found within caveolae. The fat- 1 mouse can endogenously synthesize n-3 PUFA from n-6 PUFA precursors via an omega-3-desaturase transgene (C. elegans) found in all tissues, thus, avoiding any diet-associated complications that can arise with rodent feeding trials [24]. The objective of this study was two-fold, (1) to determine the effect of n-3 PUFA on mammary gland development, specifically by altering epithelial cell populations (non-epithelial (CD24-), myo-epithelial (CD24 $4^{+/ l o w}$ ) and luminal epithelial (CD24 $4^{+/ \text {high }}$ ) cells); and (2) to determine cav-1, ER- $\alpha$ and Her-2/neu expression in caveolae extracted from mammary glands of the fat- 1 mouse.

\section{Materials and Methods}

\subsection{Ethics Statement}

This investigation was performed under Animal Utilization Protocol 07G010, which was approved by the Animal Care Committee of the University of Guelph under the governance of the Canadian Council on Animal Care. Each mammary gland sample was pooled from 6-8 mice. Thus, animal numbers were minimized to the full extent permitted by statistical rigour. For this reason, $n=3$ for both the WT and fat-1 groups.

\subsection{Animals, Diets and Phenotyping}

Fat-1 mice, originally obtained from Dr. Jing Kang (Harvard Medical School), were used from an in-house breeding colony and husbandry practices are reported elsewhere [10]. Harems were fed a modified AIN93G diet (Research Diets Inc.) ad libitum containing 10\% fat $(w / w)$ from safflower oil; providing $22 \%$ of the mouse's total daily energy requirements (Table 1). Offspring were weaned at 3 weeks of age, and phenotyped as described previously [10]. Female offspring were maintained on their parental diet for 6-8 weeks until termination.

Table 1. Composition of $10 \%$ safflower diet fed to wildtype (WT) and fat-1 mice.

\begin{tabular}{cc}
\hline Ingredient & $\mathbf{g} / \mathbf{K g}$ \\
\hline Casein & 200 \\
L-cystine & 3.0 \\
Cornstarch & 336.7 \\
Maltodextrin & 132 \\
Sucrose & 100 \\
Cellulose & 50 \\
Safflower oil & 97 \\
t-butylhydroquinone & 0.019 \\
Mineral mix S10022G & 35 \\
Vitamin Mix V10037 & 10 \\
Choline bitartrate & 2.5 \\
\hline
\end{tabular}




\subsection{Euthanization and Tissue Collection}

On the day of termination, the stage of the mouse's estrus cycle was determined by a vaginal smear. Mice in diestrus were maintained until they passed into proestrus to control for hormonal fluctuations which may impact cell proliferation profiles [25]. Mice in other stages of the estrus cycle were terminated by $\mathrm{CO}_{2}$ overdose and the right and left 4th and 5th mammary glands (MG) were excised for epithelial cell isolation.

\subsection{Epithelial Cell Characterization and Caveolae Isolation}

The 4th and 5th MGs were pooled from 6-8 mice per group $(n=3)$; lymph nodes were removed, and mammary epithelial cells were isolated using the method of Prater et al. [26]. Briefly, finely minced MGs were digested in collagenase/hyaluronidase (StemCell, cat \# 07912) for $18 \mathrm{~h}$ at $37^{\circ} \mathrm{C}$ to allow for tissue dissociation. Cells were washed in Hank's balanced salt solution (Sigma, cat \# H6648) and treated with ammonium chloride (Sigma, cat \# A9434), Trypsin/EDTA (Sigma, cat \# T4049), dispase (StemCell, cat \# 07913) and DNAase 1 (Sigma, cat \# D5025) to release the epithelial cells.

An aliquot $\left(2.5 \times 10^{5}\right)$ of isolated epithelial cells was used to determine CD24 surface expression by flow cytometry. Cells were stained on ice for $30 \mathrm{~min}$ with $0.5 \mu \mathrm{g} / \mu \mathrm{L}$ FITC-conjugated CD24 (ebiosciences, cat \# 11-0242-82, rat IgG2b, clone: M1/69), washed with $2 \mathrm{~mL}, 1 \% \mathrm{BSA} / \mathrm{PBS}$ and stained on ice for a further $30 \mathrm{~min}$ with $0.2 \mu \mathrm{g} / \mu \mathrm{L}$ PE-conjugated CD45 (ebiosciences, cat \# 12-0451-82, rat IgG2b, clone 30-F11). Cells were washed with $2 \mathrm{~mL}$ 1\% BSA/PBS and resuspended in $100 \mu \mathrm{L}$ 1\% BSA/PBS for flow cytometry using a Becton Dickenson FACSCalibur E4272 flow cytometer. Each analysis included an isotype control, namely FITC-conjugated Rat IgG2b (ebiosciences, cat \# 11-4031-81) for CD24 and PE-conjugated Rat IgG2b (ebiosciences, Cat \# 12-4031-81) for CD45. For flow cytometer analysis, cells were gated on the CD45PE-negative population and epithelial populations were defined based on the intensity of CD24FITC expression. Non-epithelial cells are CD24-, myo-epithelial cells are $\mathrm{CD} 24^{+/ \text {low }}$ and luminal epithelial cells are CD24 ${ }^{+/ \text {high }}$. Each analysis was comprised of $10^{4}$ viable cells.

Caveolae were isolated from the remaining MG epithelial cells as described by Macdonald and Pike [27]. After the last ultracentrifugation step, eleven- $1 \mathrm{~mL}$ fractions were collected starting from the liquid surface. Fractions 5-8 were caveolae-rich and were pooled for further analysis.

\subsection{Protein Expression}

Protein levels of enriched caveolae were determined by the Bradford protein assay (BioRad, Cat \# 5000001 ). Quantities of 1,2 and $5 \mu \mathrm{g}$ of protein were ran through $15 \%$ acrylamide gel with a $5 \%$ stacking gel for cav-1, ER- $\alpha$ and Her-2/neu, respectively, to determine protein expression by Western protein blotting. The separated proteins were transferred to a polyvinylidene fluoride (PVDF) membrane, blocked overnight in 5\% skim milk powder and incubated for $2 \mathrm{~h}$ at room temperature with either caveolin-1 antibody (Santa Cruz, Cat \# sc-894) diluted 1:500 or ER- $\alpha$ antibody (Santa Cruz, Cat \# sc-7207) diluted 1:200 or Her2 neu antibody (Santa Cruz, Cat \# sc-101695) diluted 1:200. All primary antibodies were followed by goat anti-rabbit IgG HRP (Santa Cruz, Cat \# sc-2030) diluted 1:1000 for $1 \mathrm{~h}$ at RT. Protein bands were detected by Western Lightening Plus ECL (Perkin Elmer, Cat \# NEL 103001EA) and visualized on a FluorChem HD2 imager (Cell Biosciences, Santa Clara, California, USA). Bands were quantified using AlphaView imaging software (Version 3.1.1.0).

\subsection{Phospholipid Fatty Acid Analysis}

Lipids were extracted from isolated caveolae via the Folch Method [28] and phospholipid fractions were separated by thin layer chromatography (TLC) [29], as previously described. Briefly, H-plates (EMD Chemicals \#5721-7) were incubated in an oven for one hour at $100{ }^{\circ} \mathrm{C}$ prior to being spotted by samples. They were then placed in a TLC tank containing $30 \mathrm{~mL}$ chloroform, $9 \mathrm{~mL}$ methanol, 25 $\mathrm{mL}$ 2-propanol, $6 \mathrm{~mL} 0.25 \mathrm{M} \mathrm{KCl}$, and $18 \mathrm{~mL}$ triethylamine. Following this, the plates were then 
lightly sprayed with $0.1 \%(w / v)$ ANSA (Fluka \#GA 12046) before being visualized under UV light. Bands corresponding to phosphatidylcholine (PC) and phosphatidylethanolamine (PE) were collected.

Methylation was performed by adding $2 \mathrm{~mL}$ of hexane and $2 \mathrm{~mL}$ of $14 \% \mathrm{BF}_{3}-\mathrm{MeOH}$ (Sigma B1252) to the samples and incubating them at $100{ }^{\circ} \mathrm{C}$ for $90 \mathrm{~min}$. Following methylation, $2 \mathrm{~mL}$ of double-distilled $\mathrm{H}_{2} \mathrm{O}$ was added to the samples and the solution was immediately vortexed for $30 \mathrm{~s}$ to halt methylation. Samples were centrifuged for $10 \mathrm{~min}$ at $357 \times g$, the hexane layer was collected and dried down under nitrogen before reconstitution in $50 \mu \mathrm{L}$ of hexane. Fatty acid methyl esters were quantified on an Agilent 6890 gas chromatograph equipped with flame ionization detection and separated on a DB-FFAP fused-silica capillary column $(15 \mathrm{~m}, 0.1 \mathrm{~m}$ film thickness, $0.1 \mathrm{~mm}$ i.d.; Agilent Cat \# 127-32H2). Samples were injected in 200:1 split mode. The injector and detector ports were set at $250{ }^{\circ} \mathrm{C}$. Fatty acid methyl esters were eluted using a temperature program set initially at $150{ }^{\circ} \mathrm{C}$ and held for $0.25 \mathrm{~min}$, increased at $35^{\circ} \mathrm{C} / \mathrm{min}$ and held at $170^{\circ} \mathrm{C}$ for $3 \mathrm{~min}$, increased at $9{ }^{\circ} \mathrm{C} / \mathrm{min}$ to $225^{\circ} \mathrm{C}$, and finally, increased $80^{\circ} \mathrm{C} / \mathrm{min}$ to $245^{\circ} \mathrm{C}$ and held for $2.2 \mathrm{~min}$. The run time per sample is $12 \mathrm{~min}$. The carrier gas was hydrogen, set to a $30 \mathrm{~mL} / \mathrm{min}$ constant flow rate. Peaks were identified by retention times of fatty acid methyl ester standards (Nu-Chek-Prep, Elysian, MN) using EZchrom Elite version 3.2.1 software. Fatty acid results were calculated as percent composition.

\subsection{Statistical Analysis}

Data was subjected to a two-tailed Student's $t$-test with a pre-set upper limit of probability for statistical significance set at $p=0.05$. SAS system for windows, version 8.2 , was used for analyses.

\section{Results}

\subsection{Epithelial Cell Populations}

Based on CD24 expression, the fat-1 mouse had a significantly altered MG epithelial cell profile, as shown in the flow cytometer histograms (Figure 1A,B) and the percent of epithelial cells expressing CD24 (Figure 2).
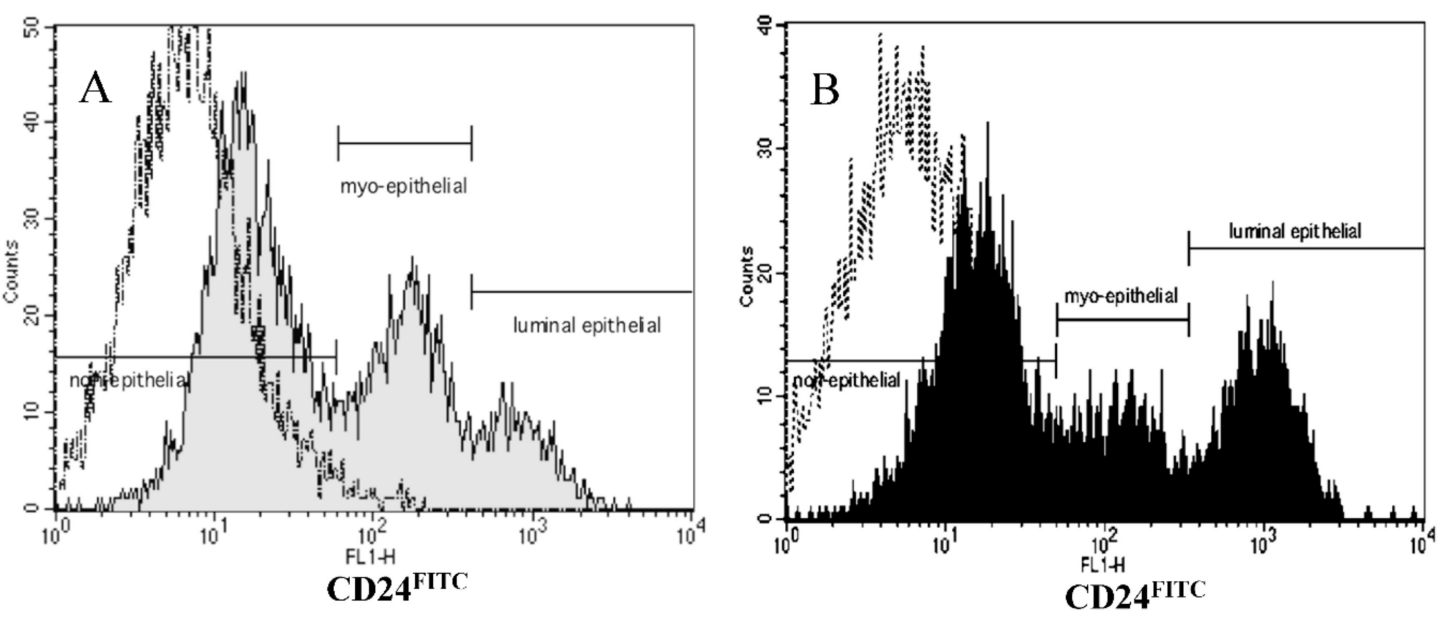

Figure 1. Representative flow cytometer histograms of mammary epithelial cell preparations for wildtype (A; grey) and fat-1 (B; black) mice. (A,B), epithelial cell populations determined by CD24 FITC staining intensity after gating out $\mathrm{CD} 45 \mathrm{PE}^{+}$cells. Rat IgG2 $\mathrm{b}^{\mathrm{FITC}}$ isotype control shown in black dotted lines. 


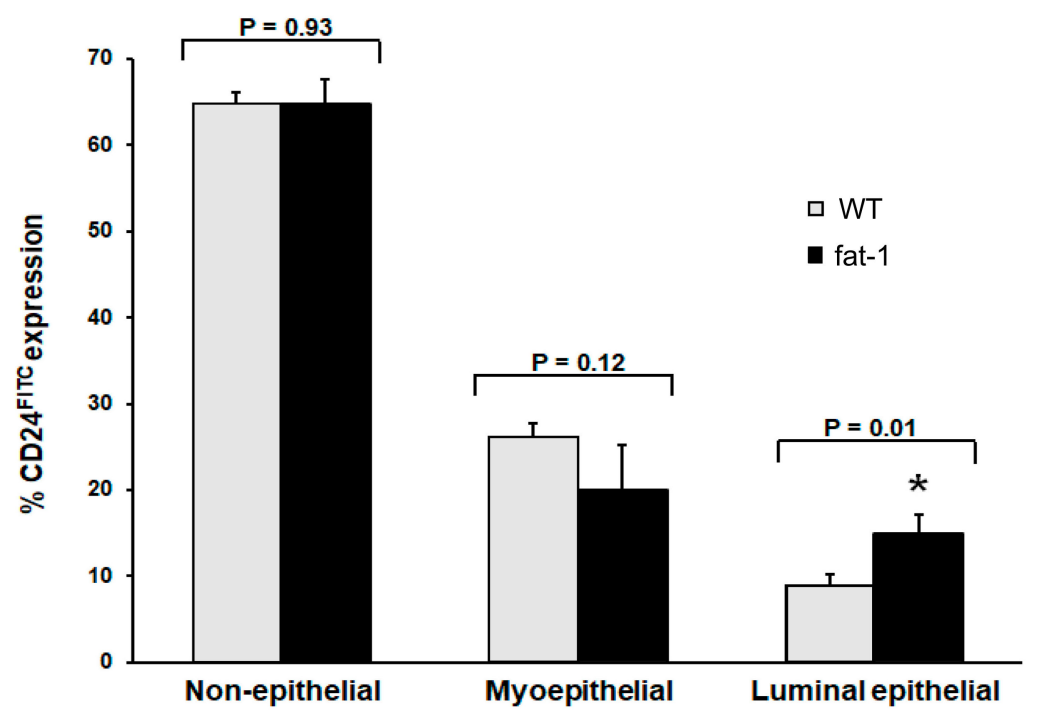

Figure 2. Percent CD24 ${ }^{\text {FITC }}$ surface marker expression on mammary epithelial cells. Bars represent means plus SD and * identifies differences $(p \leq 0.05)$ between wildtype (WT) and fat- 1 mice by Student's t-test.

The total number of mammary epithelial cells obtained from the fat- 1 and WT mice were not different $(p=0.79$ ) (Figure 3A). The fat-1 mouse expressed 65\% non-epithelial, 20\% myo-epithelial and $15 \%$ luminal epithelial cells compared to the WT mouse, which expressed $65 \%$ non-epithelial, $26 \%$ myo-epithelial, and $9 \%$ luminal epithelial cells (Figure 2). The luminal epithelial cell profile was significantly greater in the fat- 1 mouse $(p \leq 0.05)$ (Figures 1 and 2).

A

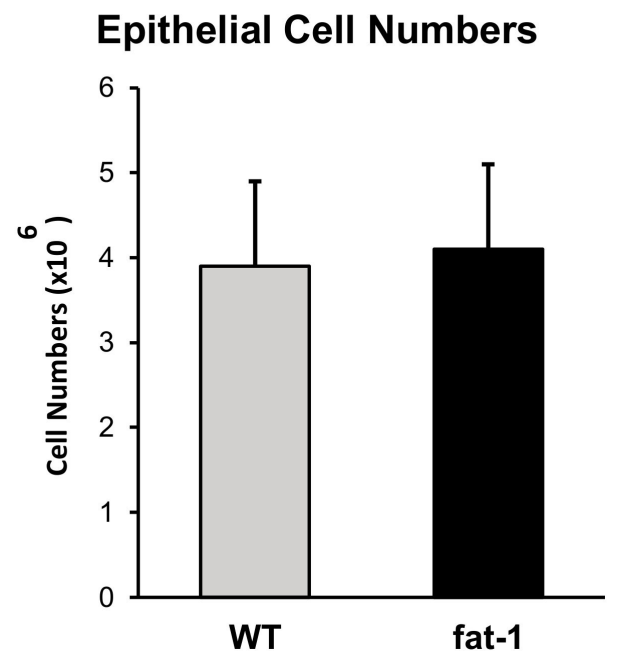

B

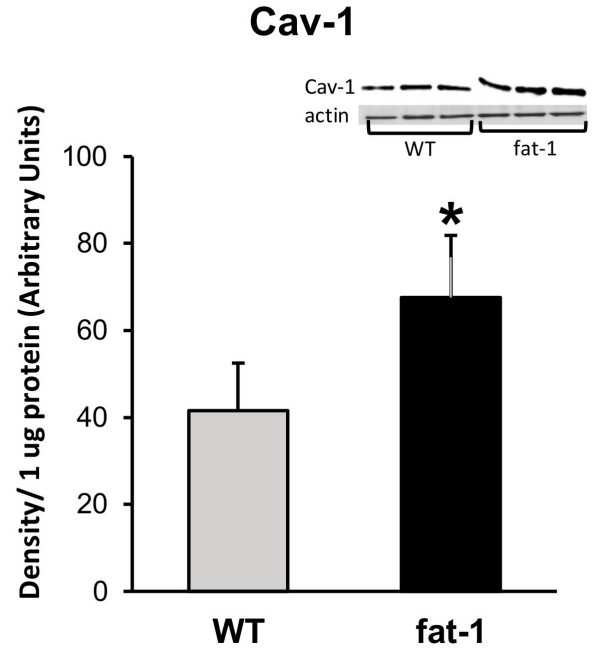

Figure 3. Cont. 
C

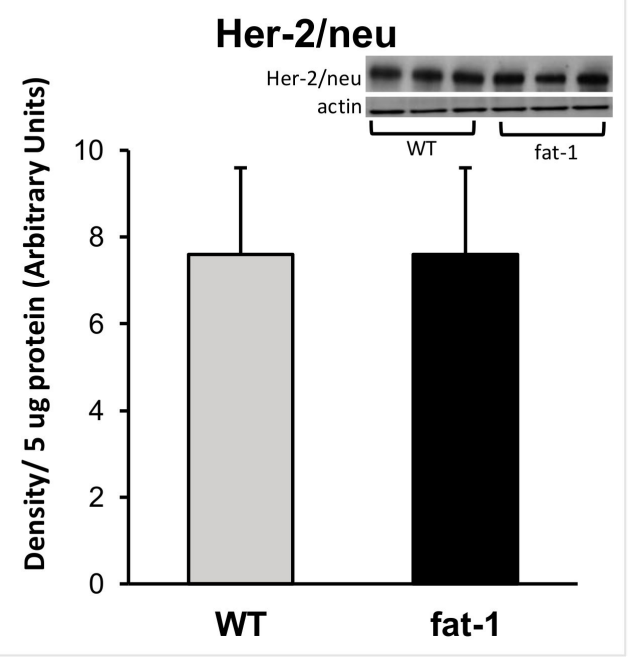

D

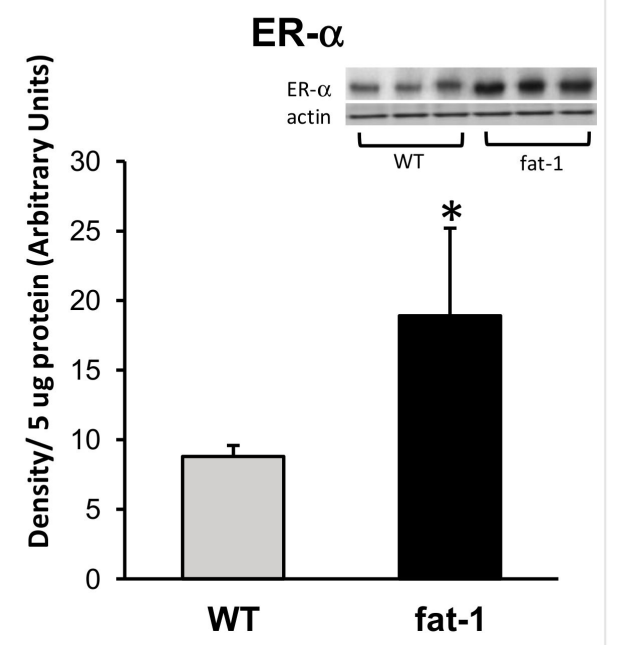

Figure 3. Epithelial cell numbers and protein expression, including representative Western blots, in caveolae isolated from mammary epithelial cells of wildtype (WT) and fat-1 mice: (A) epithelial cell numbers, (B) Cav-1, (C) Her-2/neu, (D) ER- $\alpha .{ }^{*}$ denotes a significant difference at $p \leq 0.05$ by Student's $t$-test.

\subsection{Protein Expression}

The fat- 1 mouse acquired an altered expression of cav- 1 and ER- $\alpha$ proteins in comparison to the WT mouse. In contrast to WT mice, the fat- 1 mice had a 1.5 -fold increase in cav- $1(p \leq 0.05)$ expression (Figure 3B); a two-fold increase in ER- $\alpha(p \leq 0.05)$ expression (Figure 3D); while the amount of Her-2/neu protein was not significantly different $(p=0.990)$ between groups (Figure 3C).

\subsection{Phospholipid Fatty Acids}

Within the PC fraction of the MG epithelial cells' caveolae, the fat- 1 mice had significant increases in $\alpha$-linolenic acid, eicosapentaenoic acid and docosahexaenoic acid ( $p \leq 0.05)$, and complementary decreases in linoleic acid and arachidonic acid $(p \leq 0.05)$ (Table 2). A similar trend was observed within the PE fraction of the same caveolae (Table 2).

Table 2. Percent fatty acid composition of caveolae isolated from mammary epithelial cells of wildtype (WT) and fat-1 mice: PC and PE phospholipid fractions ${ }^{1}$.

\begin{tabular}{lcccccc}
\hline & \multicolumn{3}{c}{ PC } & \multicolumn{3}{c}{ PE } \\
\hline & WT & Fat-1 & $p$ Value & WT & Fat-1 & $p$ Value \\
\hline 18:0, stearic & $44.1^{*}$ & 34.6 & $\leq 0.05$ & 50.9 & 47.1 & 0.116 \\
18:1, oleic & 19.4 & 16.7 & 0.371 & 29.2 & 32.7 & 0.214 \\
18:2n6, linoleic & $24.0^{*}$ & 15.2 & $\leq 0.05$ & $11.3^{*}$ & 4.7 & $\leq 0.05$ \\
18:3n3, alpha linolenic & 0.2 & $3.9^{*}$ & $\leq 0.05$ & 0 & $1.4^{*}$ & $\leq 0.05$ \\
20:4n6, arachidonic & $12.3^{*}$ & 8.6 & $\leq 0.05$ & $8.6^{*}$ & 2.6 & $\leq 0.05$ \\
20:5n3, eicosapentaenoic & 0 & $8.8^{*}$ & $\leq 0.05$ & 0 & $5.6^{*}$ & $\leq 0.05$ \\
22:6n3, docosahexaenoic & 0 & $12.1^{*}$ & $\leq 0.05$ & 0 & $5.9^{*}$ & $\leq 0.05$ \\
\hline
\end{tabular}

${ }^{1}$ Means of selected fatty acids are reported. Within a row and phospholipid fraction, values with a ${ }^{*} \operatorname{differ}(p \leq 0.05)$ according to Student's $t$-test between WT and fat-1 mice. PC: phosphatidylcholine, PE: phosphatidylethanolamine.

\section{Discussion}

Our lab has previously shown that lifelong exposure to n-3 PUFAs reduces both tumour volume and multiplicity in the mammary glands of MMTV-neu(ndl)-YD5 mice [8,9]. While it has been 
proposed that n-3 PUFA have the ability to alter MG development, the mechanism of action remains poorly understood. The current study has shown that the endogenous production of $n-3$ PUFA from an n-6 PUFA source has the capacity to significantly increase the luminal epithelial cell population while not altering the total number or size of epithelial cells found within the mouse's MG. Luminal epithelial cells exhibit stem cell characteristics and have the ability to differentiate into myo-epithelial cells [13]. Breast cancer is believed to arise in the luminal epithelial compartment but the relationship between luminal and myo-epithelial lineages require further examination [13]. An increase in luminal epithelial cell abundance within the MG may indicate a greater risk towards developing MG tumours. However, a greater marker of breast cancer risk than elevated amounts of luminal epithelial cells is a complete loss of myo-epithelial cells $[15,17]$. While the percentage of myo-epithelial cells within the fat-1 transgenic mice mammary glands was non-significantly reduced compared to wildtype mice ( $20 \%$ compared to $26 \%$, respectively), they still had a large proportion of myo-epithelial cells, which may provide the required ductal integrity and cellular signals to prevent tumour development.

Further, n-3 PUFA have also been shown to alter the expression of tumour-promoting and tumour-suppressing proteins. Cav-1 is a constituent protein and principle marker of caveolae. In addition, the over-expression of cav-1 has been associated with tumour suppression [21], while ER- $\alpha$ and Her-2/neu are tumour promoters [22,23]. The observed increase in cav- 1 and ER- $\alpha$ may not be contradictory given that normal cells were assessed. Thus, in the context of mammary gland development, the increase of cav- 1 expressed in the fat- 1 mouse may have protective effects against mammary tumour growth later in life. Also, recent evidence shows that cav-1 overexpression is associated with increased ER- $\alpha$ in caveolae and this protein-protein interaction inhibits ER- $\alpha$ signaling [30]. Furthermore, while the increased expression of ER- $\alpha$ may indicate a greater risk of developing cancer, it must be noted that tumours expressing increased ER- $\alpha$ lead to a promising prognosis for cancer treatment [22]. ER- $\alpha$-positive cancers are often successfully treated by endocrine therapy, whereas ER- $\alpha$-negative tumours have a poor prognosis and, generally, cannot be treated [22]. Whether this increases the risk of breast cancer or improves the prognosis of breast cancer, should it develop, requires further research with a mammary tumour mouse model. Her-2/neu is over-expressed in breast cancer and is a specific tumour marker [23]. There was no change in the expression levels of Her-2/neu between the fat- 1 and WT mice. This is likely reflective of the absence of tumours in these otherwise healthy mice. While a focus of this study has been at the level of caveolae, downstream signalling, total cellular protein expression of these proteins and gene expression were not assessed. These are important measures for future investigation in order to obtain a complete understanding of molecular, cellular and functional changes.

In conclusion, these results suggest that n-3 PUFA produced endogenously within the fat- 1 mouse can alter the proportion of epithelial populations in the developing pubertal mammary gland, which may have implications for future cancer risk. Additionally, n-3 PUFA may protect against long-term development of breast cancer by influencing cell signaling pathways mediated by caveolae during pubertal MG development at 6-8 weeks of age. Further research is warranted to conclude whether the epithelial cell profile and cav- 1 expression of the fat- 1 mouse is protective against breast cancer.

Author Contributions: D.W.L.M. and L.M.H. conceptualized the study. L.M.H. executed the study and performed all analyses. J.X.K. provided the mouse model. All authors contributed to the editing and review of the manuscript.

Funding: D.W.L. Ma is funded by a grant from the Natural Sciences and Engineering Research Council of Canada (NSERC).

Conflicts of Interest: The authors declare no conflict of interest. 


\section{References}

1. Parkin, D.M.; Bray, F.I.; Devesa, S.S. Cancer burden in the year 2000. The global picture. Eur. J. Cancer 2001, 37 (Suppl. 8), 4-66. [CrossRef]

2. Howlader, N.; Noone, A.M.; Krapcho, M.; Miller, D.; Brest, A.; Yu, M.; Ruhl, J.; Tatalovich, Z.; Mariotto, A.; Lewis, D.R.; et al. SEER Cancer Statistics Review, 1975-2011; National Cancer Institute: Bethesda, MD, USA, 2014. Available online: https://seer.cancer.gov/archive/csr/1975_2011/ (accessed on 11 December 2018).

3. Ferlay, J.; Shin, H.R.; Bray, F.; Forman, D.; Mathers, C.; Parkin, D.M. Estimates of worldwide burden of cancer in 2008: Globocan 2008. Int. J. Cancer 2010, 127, 2893-2917. [CrossRef] [PubMed]

4. Saika, K.; Sobue, T. Cancer statisitcs in the world. Gan Kagaku Ryoho Cancer Chemother. 2013, 40, $2475-2480$.

5. Jemal, A.; Center, M.M.; DeSantis, C.; Ward, E.M. Global patterns of cancer incidence and mortality rates and trends. Cancer Epidemiol. Biomarkers Prev. 2010, 19, 1893-1907. [CrossRef] [PubMed]

6. Kachuri, L.; De, P.; Ellison, L.F.; Semenciw, R.; Advisory Committee on Canadian Cancer Statistics. Cancer incidence, mortality and survival trends in Canada, 1970-2007. Chronic Dis. Inj. Can. 2013, 33, 69-80. [PubMed]

7. Iwasaki, M.; Tsugane, S. Risk factors for breast cancer: Epidemiological evidence from Japanese studies. Cancer Sci. 2011, 102, 1607-1614. [CrossRef] [PubMed]

8. MacLennan, M.B.; Clarke, S.E.; Perez, K.; Wood, G.A.; Muller, W.J.; Kang, J.X.; Ma, D.W. Mammary tumor development is directly inhibited by lifelong n-3 polyunsaturated fatty acids. J. Nutr. Biochem. 2013, 24, 388-395. [CrossRef]

9. Leslie, M.A.; Abdelmagid, S.A.; Perez, K.; Muller, W.J.; Ma, D.W. Mammary tumour development is dose-dependently inhibited by n-3 polyunsaturated fatty acids in the MMTV-neu(ndl)-YD5 transgenic mouse model. Lipids Health Dis. 2014, 13, 96. [CrossRef]

10. MacLennan, M.B.; Anderson, B.M.; Ma, D.W. Differential mammary gland development in FVB and C57Bl/6 mice: Implications for breast cancer research. Nutrients 2011, 3, 929-936. [CrossRef]

11. Russo, J.; Tay, L.K.; Ciocca, D.R.; Russo, I.H. Molecular and cellular basis of the mammary gland susceptibility to carcinogenesis. Environ. Health Perspect. 1983, 49, 185-199. [CrossRef]

12. Olivo, S.E.; Hilakivi-Clarke, L. Opposing effects of prepubertal low- and high-fat n-3 polyunsaturated fatty acid diets on rat mammary tumorigenesis. Carcinogenesis 2005, 26, 1563-1572. [CrossRef] [PubMed]

13. Gudjonsson, T.; Adriance, M.C.; Sternlicht, M.D.; Petersen, O.W.; Bissell, M.J. Myoepithelial cells: Their origin and function in breast morphogenesis and neoplasia. J. Mammary Gland Biol. Neoplasia 2005, 10, 261-272. [CrossRef] [PubMed]

14. Sternlicht, M.D.; Kedeshian, P.; Shao, Z.M.; Safarians, S.; Barsky, S.H. The human myoepithelial cell is a natural tumor suppressor. Clin. Cancer Res. 1997, 3, 1949-1958. [PubMed]

15. Gusterson, B.A.; Warburton, M.J.; Mitchell, D.; Ellison, M.; Neville, A.M.; Rudland, P.S. Distribution of myoepithelial cells and basement membrane proteins in the normal breast and in benign and malignant breast diseases. Cancer Res. 1982, 42, 4763-4770. [PubMed]

16. Gudjonsson, T.; Rønnov-Jessen, L.; Villadsen, R.; Rank, F.; Bissell, M.J.; Petersen, O.W. Normal and tumor-derived myoepithelial cells differ in their ability to interact with luminal breast epithelial cells for polarity and basement membrane deposition. J. Cell Sci. 2002, 115, 39-50.

17. Rudland, P.S. Stem cells and the development of mammary cancers in experimental rats and in humans. Cancer Metastasis Rev. 1987, 6, 55-83. [CrossRef]

18. Aoki, M.N.; Amarante, M.K.; Oda, J.M.; Watanabe, M.A. Caveolin involvement and modulation in breast cancer. Mini Rev. Med. Chem. 2011, 11, 1143-1152. [CrossRef]

19. Hnasko, R.; Lisanti, M.P. The biology of caveolae: Lessons from caveolin knockout mice and implications for human disease. Mol. Interv. 2003, 3, 445-464. [CrossRef]

20. Sotgia, F.; Martinez-Outschoorn, U.E.; Howell, A.; Pestell, R.G.; Pavlides, S.; Lisanti, M.P. Caveolin-1 and cancer metabolism in the tumor microenvironment: Markers, models, and mechanisms. Annu. Rev. Pathol. 2012, 7, 423-467. [CrossRef]

21. Patani, N.; Martin, L.A.; Reis-Filho, J.S.; Dowsett, M. The role of caveolin-1 in human breast cancer. Breast Cancer Res. Treat. 2012, 131, 1-15. [CrossRef]

22. Giacinti, L.; Claudio, P.P.; Lopez, M.; Giordano, A. Epigenetic information and estrogen receptor alpha expression in breast cancer. Oncologist 2006, 11, 1-8. [CrossRef] [PubMed] 
23. Molina, R.; Escudero, J.M.; Muñoz, M.; Augé, J.M.; Filella, X. Circulating levels of Her-2/neu oncoprotein in breast cancer. Clin. Chem. Lab. Med. 2012, 50, 5-21. [CrossRef] [PubMed]

24. Kang, J.X.; Wang, J.; Wu, L.; Kang, Z.B. Transgenic mice: Fat-1 mice convert n-6 to n-3 fatty acids. Nature 2004, 427, 504. [CrossRef] [PubMed]

25. Marcondes, F.K.; Bianchi, F.J.; Tanno, A.P. Determination of the estrous cycle phases of rats: Some helpful considerations. Braz. J. Biol. 2002, 62, 609-614. [CrossRef]

26. Prater, M.; Shehata, M.; Watson, C.J.; Stingl, J. Enzymatic dissociation, flow cytometric analysis, and culture of normal mouse mammary tissue. Methods Mol. Biol. 2013, 946, 395-409.

27. Macdonald, J.L.; Pike, L.J. A simplified method for the preparation of detergent-free lipid rafts. J. Lipid Res. 2005, 46, 1061-1067. [CrossRef]

28. Folch, J.L.M. A simple method for the isolation and purification of total lipids from animal tissues. J. Biol. Chem. 1957, 226, 497-509.

29. Touchstone, J.C.; Chen, J.C.; Beaver, K.M. Improved separation of phospholipids in thin layer chromatography. Lipids 1980, 15, 61-62. [CrossRef]

30. Razandi, M.; Oh, P.; Pedram, A.; Schnitzer, J.; Levin, E.R. ERs associate with and regulate the production of caveolin: Implications for signaling and cellular actions. Mol. Endocrinol. 2002, 16, 100-115. [CrossRef]

(C) 2019 by the authors. Licensee MDPI, Basel, Switzerland. This article is an open access article distributed under the terms and conditions of the Creative Commons Attribution (CC BY) license (http://creativecommons.org/licenses/by/4.0/). 